Mukaddime, 2021, 12(1), s. 100-117.

DOI: $10.19059 /$ mukaddime.854281

\title{
Osman Şahin'in “Beyaz Öküz” Adlı Hikâyesinde Aşk ve Namus İkilemi
}

Selami ÇAKMAKÇ ${ }^{1}$

\section{Öz}

Hikâye serüveni 1970'li yılların başından itibaren başlayan Osman Şahin, günümüzde de bu etkinliğini sürdüren bir yazardır. Hikâye, inceleme, roman, masal, derleme ve deneme gibi edebiyatın birçok alanında kalem tecrübesine sahiptir. Maupassant tarzı hikâye anlayışıly yazan Şahin, bu alanda birçok ödülün sahibidir. Toplumcu gerçekçi edebiyat anlayışına bağlı olan yazarın, Acı Duman adlı kitabındaki Beyaz Öküz hikâyesi de bu sanat anlayışına göre şekillenir. Bu anlayışı, söz konusu hikâyede "ezen-ezilen" şablonu şeklinde kendini belli eder. Çocukluk yıllarından itibaren yaşadığı yoksulluğun kendi iç dünyasında bıraktığı etkiyi bu hikâyesindeki yoksul insanların dünyasından hareketle ele alır. Halk kültürü üzerine çalışmaları da bulunan yazarın bu özelliğinin metne yansıdığı görülür. Aşk denilen coşku ve heyecan Osman Şahin'in Beyaz Öküz adlı hikâyesinin de temel konularından biridir. Yoğun bir içeriğe sahip hikâyede töre, ezilmişlik, korku, kıskançlık, batıl inanışlar, ağa-ırgat ilişkileri, ölüm, kin, nefret ve pişmanlık gibi birçok unsurla karşılaşılır. Toroslardaki yoksul geçen çocukluğu ile görev yaptığı Doğu'daki gözlemlerinden izler taşıyan hikâyede yazarın malzemesi toplumsal gerçeklerdir. Yazar, hikâyede insanları kendi çevreleri içinde ele alarak savunduğu ideolojiyi daha inandırıcı hzale getirmek istemiştir. Yüzlerce yıllık bir gelenekten; "ağaırgat” ilişkilerinden hareket eden yazar, yoksul insanların bu geleneğin altında ezildiğini göstermekle birlikte kırsal kesimde duyguları yok sayılan kadının hikâyesini metne taşır. Çalıșmanın amacı, Osman Şahin'in Beyaz Öküz hikâyesinden hareketle belli bir yöredeki insanın var oluş mücadelesi ile toplumsal gerçeklerine ayna tutmaktır. Çalışmada hikâyeye metin merkezli yaklaşılarak bir çözümleme yapılmıştır.

Anahtar Kelimeler: Aşk, namus, yoksulluk, ikilem, toplumsal değerler.

1 Dr. Öğr. Üyesi, Kahramanmaraş Sütçü İmam Üniversitesi Eğitim Fakültesi Türkçe ve Sosyal Bilimler Eğitimi Bölümü, selamicak23@hotmail.com, ORCID ID: 0000-0002-3350-0373. 


\title{
The Conflict of Love and Honour in Osman Şahin's “Beyaz Öküz” Story
}

\begin{abstract}
Osman Şahin is a writer whose story adventure continues since the early 1970s. The writer, who has experience in many fields of literature such as story, review, novel, tale, compilation, essay, is well-known with many awards in the field of story. Şahin, who writes with a Maupassant style of story, displays an attitude that is connected to the socialist realist understanding of literature in the story of White Ox. This understanding manifests itself in the story in question as a pattern of oppressoroppressed. This characteristics of the writer, who also has works on folk culture, is reflected in his text. It is possible to see the impact of poverty on his inner world since his childhood years in the world of poor people in this story. Enthusiasm and excitement called love is also one of the main topics of Osman Şahin's story called "The White Ox". In this story, which has an intense content, many elements such as custom, oppression, fear, jealousy, superstitions, lord-lord relations, love, death, grudge, hatred, regret are encountered. The material of the writer in the story is social facts, which bear traces from his observations in the East where he worked and with his poor childhood memories in Toros. The author wants to make the ideology he defended more believable by describing people in the story within their own environment. The writer shows that the poor people are oppressed under the tradition based on the relationship between the lord and the warden from a centuries-old tradition, but also he carries the story of the woman whose feelings are ignored in the rural areas. The aim of the study is to mirror the struggle for existence and social realities of people in a certain region, based on Osman Şahin's White Ox story. In the study, an analysis was made by approaching the story with a text-centered approach.
\end{abstract}

Keywords: Love, honor, poverty, guandary, social values.

\section{Extended Abstract}

Osman Şahin is one of the authors who graduated from a "Köy Enstitüsü". His understanding of art is in social realist and his interest in literature goes back to his school years. The real life of the village and the villagers has a great place in the stories he wrote based on this understanding of art. The author, who produces works in genres such as story novel, essay, compilation and review, is mostly known for his storyteller identity. He makes a name for himself with many awards he received in the field of stories. The author has thirteen story books. He published seven story books consecutively in the Red Yel from 971, when he published his first story book, until 1993. This characteristic of the author who has also works on folk culture, has been reflected in his stories. The fact that the White Ox includes superstitious beliefs and proverbs and idioms is an indication that it benefits from the public and oral culture. Since he is social realist author, he builds his stories on the pattern of oppressor-oppressed. Beyaz Öküz, 
which is included in the Acl Duman story book, which has the characteristics of the story of the event, is a text composed of a narrow staff. In the story, the plot is shaped by Küçük Ağa, who follows Zeli, a young bride of three months, and Zeli's husband Keto, who learns about this situation and deals with the matter of honour. The setting of the story is one of the villages on the banks of the Murat river, which passes by Elazig's Palu district. In the story, events in the Anatolian geography are handled in a realistic way. The White Ox story was written with the Maupassant style. The fact that he is connected to the socialist realist understanding of literature makes the pattern of the oppressor-oppressed in the story inevitable. Also, traces of his own life have been observed in the story because it is possible to see the impact of poverty on his inner world since his childhood years on the world of poor people. Love is one of the two main subjects of Osman Şahin's story called White Ox. It is possible to encounter many elements such as custom, oppression, fear, jealousy, superstitions, agha-labourer relations, love, death, grudge, hatred, and regret in this intensive story. The writer uses social facts in the story which have traces from his observations in the East where he worked with his poor childhood in the Taurus. The writer tries to make the ideology he defended more convincing by describing people in the story within their own environment. Based on the agha-labourer relations which dates back centuries ago, the writer aims to show that the poor people are oppressed under this tradition, and the women whose feelings are ignored in the rural areas and men act far from logic in the face of the pressure of social norms. The aim of this study is to reveal the realities of people who have been under the pressure of the agha for centuries and their struggle with these realities. The White $O x$ is an event story. As in most stories, the characters were chosen from the countryside. This story has also a surprising end as in the event stories. In addition, the dilemma between the love of the heroine and honour in the story keeps the tension alive. Throughout the story, Ketone's ambition, anger, and jealousy, and Zeli's remorse, are other elements that keep the tension. Like many of his stories, Osman Şahin brought the realities of human and society he observed in the Eastern and South Eastern Anatolia regions, where he served, to this story. This story, in which his observations of his environment are reflected, also includes some social criticisms. It realistically shows what Anatolian people can do for the sake of their honour and that they can be blinded by their love. It reflects the feelings of the human being through symbols such as mirror, night and earth in the text. The mirror is an object of remembrance, night is the symbol of evil, and the earth is an element that covers all evil. The outcome of the story that ends with a surprising ending is determined by the value judgments of the society. One loses his life by acting against social morality with the courage of being a "agha", that is, holding the power, and the poor person, on the other hand, imprisoned himself in his own prison, as well as feeling the comfort of rushing to save his own honour. The values of the society are hidden behind the idea of telling about the events that caused the chief person to regret, and punishing Küçük Ağa with death. The author emphasizes that the people of the East, while living according to 
their traditions, also built a wall for themselves with these traditions and entered a deadlock. However, what the author really wants to emphasize in the event is that the will of the women in this region was taken away from them and that they should suppress their feelings under any circumstances. He also wants to show that people who are financially weak in Eastern society know their honour as the reason to live and see their honour above all else. The rituals that gave concrete form to the religious beliefs after the disappearance of Küçük Ağa and the superstitious beliefs about his discovery are the highlights that the author criticizes the region in the background. 


\section{Giriş}

1940 yılında Mersin'de doğan Osman Şahin, köy enstitüsünü bitirmiş yazarlardandır. Edebiyata olan ilgisi okul yıllarında başlar. Yazar, sanat anlayışı bakımından toplumcu gerçekçi çizgide olduğunu savunur. (Güzel, 2013: 110). Bu sanat anlayışından hareketle yazdığı hikâyelerinde köy ve köylünün gerçeği önemli yer tutar. Osman Şahin'in, gözlemlediği olaylara bir hikâye formu kazandırarak onu sanatın imkânlarıyla okura sunduğu görülür.

Hikâye roman, deneme, derleme ve inceleme gibi türlerde eser veren yazarın ilk hikâyesi 1971'de yazdığı Kırmızı Yel'dir. Osman Şahin'in birçok Avrupa diline çevrilen hikâyelerinin bazıları da Çince'ye çevrilmiştir. Şahin'in yirmiden fazla hikâyesi ise film senaryosu hâline getirilmiştir. Yazarın on üç hikâye kitabı bulunmaktadır. Daha çok hikâyeci kimliği ile tanınan yazar 1971'de yayınladığı Kırmızı Yel'den 1993'e kadar art arda yedi hikâye kitabı yayınlar.

Toplumcu gerçekçi bir edebiyat anlayışına bağlı olduğundan hikâyelerini ezen-ezilen şablonu üzerine kurar. Olay hikâyesinin özelliklerini taşıyan Acı Duman hikâye kitabında yer alan Beyaz Öküz, ${ }^{2}$ dar şahıs kadrosundan oluşan bir metindir. Hikâyede olay örgüsü, üç aylık bir körpe gelin Zeli'nin peşine takılan Küçük Ağa ve bu durumu öğrenen Zeli'nin kocası Keto'nun Küçük Ağa'nın niyetini öğrenmek için kurduğu tuzak sırasında öfkesine yenilerek onu öldürmesi ve Beyaz Öküz'ün yattığı yerin altına gömmesi üzerine şekillenir. Anadolu coğrafyasındaki olayların gerçekçi bir şekilde ele alındığı hikâye, Elazı̆̆’ın Palu ilçesinin yanından geçen Murat nehri kıyısındaki köylerden birinde yaşanır. Hikâyenin olay örgüsü kısaca şöyledir:

Keto karısı Zeli'yi komşu köylerden birinden üç ay önce kaçırmış ve yoksul olduğundan Cercis Ağa'nın yanına sığınmış, onun yanında ırgat olarak çalışmaya başlamıştır. Karı kocanın Cercis Ağa'nın yanında kaldıkları yer ise; yer damı denilen bir ahırdır. Ahırda yattıkları yerin yanında iki de öküz bulunmaktadır. Keto ile karısı Zeli durumlarından çok fazla şikâyetçi değildirler, çünkü yoksulluk onları bu şekilde yaşamaya mecbur kılmaktadır. Ancak Cercis Ağa'nın kardeşi Küçük Ağa'nın, Zeli'den etkilenip sürekli peşinde gezmeye başlaması ile her şey birden bire değişir. Zeli bundan rahatsızlık duysa da Küçük Ağa bir türlü peşini bırakmaz. Küçük Ağa'nın Zeli'ye ilgisinin gün geçtikçe artması ve ona hediyeler vermesi Zeli'yi huzursuz eder. Nereye gitse Küçük Ağa'nın gölgesi üzerindedir. Zeli, Küçük Ağa'nın bakışlarından ve ilgisinden hoşlansa da adının çıkmasından ve bu olayın duyulmasından korkar. Ayrıca namusuna leke geleceğini düşünerek duygularını dışa vuramaz. Ancak kocasının olanları bir gün başkalarından duyacağından korkarak bu durumdan ona bahseder. Keto bu durumu öğrenince şaşırır ve ne yapacağını çaresizce düşünmeye başlar. Hikâyenin bu noktasında gerilim de yükselmeye başlar. 
Zeli, başına gelenleri kocasına söylemesiyle birlikte aklı ile kalbi arasında bir içsel çatışma yaşamaya başlar. Keto ise eğer Küçük Ağa'yı karşısına alırsa bu köyden onları kovacağını bilmektedir. Zamanın sonbahar, önlerinin kış olduğu bu günlerde ayrıca gidebilecekleri, sığınacakları başka bir yer de yoktur. Dolayısıyla bir taraftan yoksulluğunu düşünmekte, diğer taraftan ise karısının namusunu korumak zorunda olduğunu düşünmektedir. Çileden çıkan Keto, bu dünyada Zeli'den başka nesi olduğunu düşünerek onun namusunu korumanın gerçek görevi olduğunu düşünür. Diğer taraftan karısının söylediklerinden kuşku duymaz değildir. Çünkü Küçük Ağa'nın onca maraba karısının içinde Zeli’ye vurulmasını, ona göz koymasını mantığı bir türlü almamaktadır. Bu kuşkuyla yatıp kalkamaz olduğundan karısının duygularından emin olmak için bir plan yapar. Cercis Ağa'ya muhtaç olduğunu bildiğinden onun kardeşi ile açıtan bir mücadeleye girmenin yanlış olacağını düşünür. Keto olan biteni iyi anlamak için bir akşamüzeri Küçük Ağa'nın ağabeyi Cercis Ağa'nın yanına varır ve Palu'da bazı işleri olduğunu bu nedenle işlerini halletmek için gece yola çıkıp ertesi gün döneceğini söyler. Küçük Ağa ile yemek yiyen Cercis Ağa bu duruma bir anlam veremese de Keto'nun ısrarına karşı bir şey söylemez ve ona gereken izni verir. Keto'nun gece Zeli'nin yanında olmayacağını düşünen Küçük Ağa, bu durumu fırsat bilerek Zeli'nin yanına gitmek için kendi planını yapar. Keto, o akşam Palu'ya gitmek bahanesiyle köyün dışına çıkarak ters yoldan tekrar evine geri döner ve gece geç saate kadar bekleyerek Küçük Ağa'nın gelmesini bekler. Bu arada Zeli'nin, kocasının planından haberi vardır. Keto perdenin arkasına saklanarak Küçük Ağa'nın gelmesini bekler. Gecenin ilerleyen saatlerinde Küçük Ağa gelir ve Zeli'ye iltifatlar etmeye başlar. Küçük Ağa'ya gerekli tepkiyi göstermeyen Zeli, o sırada lambayı söndürünce öfkesini ve kıskançlığını kontrol edemeyen Keto saklandığı yerden Küçük Ağa'nın üzerine atlayarak bıçakla onu öldürür. Bu durumda hem Keto hem de Zeli büyük bir korku ve tedirginlik yaşarlar. Keto, Küçük Ağa'yı ortadan kaldırmak için fazla zaman olmadığını anlayınca onu ahırdaki Beyaz Öküz'ün altına gömmekten başka çare olmadığını anlar. Küçük Ağa'yı Beyaz Öküz'ün altına gömen Keto, gece hızlıca yola çıkarak Palu'ya gider ve ertesi gün köye geri döner. Birkaç gün haber alınamayan Küçük Ağa için her yere haber salınır ancak bir türlü bulunamaz. Bu arada onun için Cercis Ağa şıhlara başvurur. Şıhlar sofralarda ağır yemekler yiyerek derin uykuya dalıp Küçük Ağa'nın akıbetini öğrenmek isterler. Ayrıca kızgın tavada kurşunlar dökülerek çıkan şekillere göre anlamlar uydurulur. Ancak aylarca aramadan sonra ne dirisi ne de ölüsüne dair hiçbir iz bulunamaz. Küçük Ağa'nın gömüldüğü yerden birkaç adım ötede yatıp kalkan Zeli, Beyaz Öküz'e artık bakamaz olur. Keto, olanların unutulmasını ve kimseye bir şey hissettirilmemesini beklerken Zeli'nin her geçen gün içine kapanmasından huzursuz olur. Keto, karısını bir müddet kendi haline bıraksa da bir sonuç alamaz. Günlerce kendisiyle bir kelime konuşmayan Zeli, sürekli bu hayvana bakarak ağıtlar yakar. Keto bir gece uykudayken hüzünlü bir ninni sesi duyar. Gözlerini açtığında Zeli'nin Beyaz Öküz'e bakarak ağıt yaktığını ve ağladığını görür. Gözlerine inanamayan Keto, öfkeyle yerinden fırlayarak eline aldığı bıçağı Beyaz Öküz'e saplar. Hikâye de burada son bulur. 


\title{
1. Așk
}

Aşk denilen coşku ve heyecanın bu hikâyede anlam kazanmasının en önemli sebebi gizli yaşanılan bir duygu olmasıdır. Aşkın, hikâyede üç karakterin de hayatını değiștirmiş olması (Yılmaz, 2010: 64) bakımından da önemi büyüktür. Beyaz Öküz adlı hikâye Küçük Ağa'nın genç ve güzel, giyimi kuşamı ile herkesten farklı bir kadın olan Zeli’ye ilgisini anlatan aşağıdaki satırlarla başlar:

\begin{abstract}
Nereye gitse o adamı görüyor Zeli, o kıvırcık kara saçlı adamı. Nereye gitse hangi yöne dönse çevresi onun. Adam geriden geriye durarak, bıyıklarını burarak, enine boyuna süzerek bakışlarını kuşatıyor. Zeli'yi. Her gün böyle bu. Her gün bakışlarıyla peşinde Zeli'nin (...) Zeli farkında her şeyin. Sezinliyor bu bakışların altında yatan gerçeği. (s. 114).
\end{abstract}

Küçük Ağa sevdiğini belli etmek, onunla konuşmak için bir fırsat kollamaktadır. Küçük Ağa tarafından takip edilen ve daha ilk karşılaştığı günden itibaren ondan etkilenen Zeli, bu durumdan hem korkar hem de hoşuna gider. Zeli, hem güzeldir hem de çekicidir. "Sevgi besinini sevgilinin ya gerçekte ya da imgelemde görülen çekiciliğinden alır.” (Gasset, 2011: 67). Dolayısıyla Küçük Ağa’yı onun peşinde koşmasına iten şey Zeli'nin başka kadınlara benzememesidir:

Zeli güzel, alımlı üstelik. Sessiz yumuşak yüzlü. Gözleri siyah irisi. Göğüsleri selli. Saçları parlak; budanmış bağ suyuyla yıkanmış sanırsın. (s. 112).

Zeli'nin ona olan sevgisi de yine başka erkeklerden farklı olması ve kadınlığına verdiği değerle ilișkilidir. "Yeğlediğimiz insan tipi, kendi yüreğimizin çizgilerini taşıyan kişidir.” (Gasset, 2011: 61). Anlatıcı Zeli ve genç adamın iç dünyasından şöyle bahseder:

\footnotetext{
Boyu genç, yeşil adamın. Giyimi kuşamı yerinde. Zeli, için için hoşlanıyor bu adamın bakışlarından. Kadınlık gururunu okşuyor, ayağa kaldırıyor. Ama dışına vurmuyor bunu. Tedirgin Zeli. Görünmekten korkuyor. Adının çıkmasından, duyulmasından korkuyor. Çünkü Zeli evli. Zeli henüz üç aylık bir körpe gelin daha. Maraba ketonun karısı o. Keto, ta Hurig köyünden kaçırıp getirmiş onu. (s. 114).
}

Zeli, karşısındaki adamın öyle sıradan biri olmadığını bilse de ondan etkilendiğini dışa vuramaz. Zeli'nin yüreğinin sesi Küçük Ağa'dan yana olsa de "hayvan bağlayacakları kazığın yerini bile gösteren bu adama" tepki göstermekten çekinmektedir. Ancak Küçük Ağa bir gün yine karşısına çıkıp "bakışlarıyla onu çepeçevre kuşatınca" Zeli ne yapacağını ne diyeceğini şaşırmakla birlikte onun bakışlarında hovardaca bir anlatım olmadığını ve kendisini gerçekten sevdiğini anlar. "Aşkta anlaşma vasıtası gözdür." (Aktaş, 2004: 63). Küçük Ağa onun peşini bırakmamakta ısrarlıdır. Bir gün Murat nehrinden kovayla su getirdiğinde Zeli'nin yanına para, saç tokası ve çiçek bırakır, ancak o bunlara aldırmaz. Namusuna söz gelmemesi için aşkından vazgeçmek zorunda olduğunu bilir. Zeli'nin, bu olayın ardından koşup hemen eve gelir. Kocası, ne olduğunu merak edip sorunca, Küçük Ağa'nın kendisine vermek istediği hediyelerden bahseder. Ancak Zeli, kendisinin bu hediyelere dokunmadığını söylese de içine aşk ateşi düşmüştür. Zeli, bir süre olanları kocasına söyleyip söylememek ikilemini yaşar. Ancak kocası olanları her 
şeyi anlatmayı daha mantıklı bulur. Onun, bu olayı Keto’ya söylemesi hikâyenin ilk gerilim noktasıdır:

Zeli ikirciklendi. Söylese miydi söylemese miydi? Ya olanları bir gün kocası başkasının ağzından duyarsa? Zeli başını eğdi. Dilinin ucuna seslenir gibi usulca:

“Küçük Ağa” dedi.

“Ne olmuştur Küçük Ağa'ya?”

“Bana bakiy." (s. 116).

Keto, olanlara bir anlam veremediği gibi inanası da gelmez. Çünkü şimdiye kadar Küçük Ağa'nın hiçbir maraba karısına göz koyduğunu duymamıştır. Bu olay Zeli'nin Küçük Ağa'yla ilk karşılaşmasından itibaren iç dünyasında yaşadığı aşk ve namus ikileminin de başlangıcıdır. Hikâyede söz konusu gerilim kocası Keto'nun Küçük Ağa'yı öldürmesiyle en üst seviyeye çıkacaktır. Zeli, Murat nehrine bir gün yine su kabını doldurmak için inince atıyla kendisini bekleyen Ağa'yı yeniden orada görür. Anlatıcı Zeli'nin bu durumunu; “üstünde kartal dolanan yavru bir tavşan” şeklinde tasvir eder. Zeli, nehir kıyısında bekleyen küçük Ağa’yı görünce ona sırtını döner. Bu defa Küçük Ağa onun eteğine biraz para ve bir de cep aynası bırakır:

O ara sağ omuzundan önüne doğru uzanan Ağa'nın kıllı beyaz elini gördü. El, tuttuğu parayı Zeli'nin eteğine koyup çekildi. Küçük Ağa'nın gölgesi Zeli'nin üstündeydi daha. Aynı el tekrar uzandı. Bu kez ayna vardı Küçük Ağa'nın avucunda. Ufacık, düz, yuvarlak bir cep aynası. El kalktı, aynayı ağır ağır Zeli’nin yüzüne doğru tuttu. Garip telaşlı, bocalayan yüzünü aynada gördü Zeli. Küçük Ağa'yla kendini aynada gördü. Terledi, gözlerini yumdu bir an. Açtığında Küçük Ağa aynanın içinde yoktu. Aynayı da paranın yanına koyup gitmişti Küçük Ağa. Zeli derin bir soluk aldı. Çok ağır bir yükün altından kalkmıştı sanki. Doğruldu. Eteğine konulan parayla aynayı alarak hızla uzaklaştı oradan, gözden yitip gitmiş öküzlere doğru... Küçük Ağa gitmiş değildi oysa. Bir çalı kümesinin arkasına çömelmiş, koyduklarının alınıp alınmadığını izliyordu. Zeli'nin aynayla parayı aldığını görünce sevindi. (s. 119).

Onu bir çalının arkasından izleyen Küçük Ağa, Zeli'nin eteğine bırakılan hediyeleri alıp uzaklaştığını görünce oldukça sevinir. Daha önce reddedilen hediyelerin şimdi kabul edildiğini görmenin sevinci, aşklarını gizli yaşayanlar için bir kabul görme veya aşkının onaylanması anlamına gelir. "Doğrusu aşklar bir mendilin verilişindeki gizlilikten, uzaktan uzağa tutulan cep aynasının parıltısından, hızla yeşerip soluveren bir gülümsemenin renginden ya da ani bir bakışın sınırlarından öteye gidemezdi." (Toptaş, 2018: 108). Beyaz Öküz'deki Zeli-Küçük Ağa aşkının da; gizlilik, uzaktan sevmek, hediye vermek ve bakış gibi söz konusu unsurları içerdiği çok açıktır. Küçük Ağa, bu hediyeleri almasını onun kendisini sevdiğinin işareti olarak yorumlar. Küçük Ağa'nın verdiği ayna zamanla Zeli ile onun arasındaki aşkın simgesi olur. Zeli'nin bu hediyeler arasında "ayna"dan kocasına bahsetmemesi ve onu saklaması Küçük Ağa'nın Zeli'nin dünyasında yaşamaya devam ettiğinin; onu sevdiğinin gerçek işaretidir:

Zeli aldığı parayı aynı akşam kocasına verdi. Ancak aynadan söz etmedi. Ayna, Küçük Ağa ile kendisi arasında incecik bir sır olarak kaldı. (s.120). 
Duyguları açığa vurma bakımından hatırlama nesnesi konumundaki ayna, Zeli ile Küçük Ağa'nın birbirine duydukları aşkın bir simgesidir. "Eşya kendisi olmaktan çıkarak, kahramanın haleti ruhiyesinin daha iyi anlatılabildiği bir vasıtaya dönüşür." (Şakar, 2014: 160). Ayna çağrışım olarak "Türk şairlerinin bellek metaforu olarak en çok konumlandırdıkları bir nesnedir. Ayna birçok sanat dalında belleği imler." (Tunç, 2020: 118-119). Ayna, kadının belleğinde bir sır olarak metnin en önemli nesnesidir. Ayna, Zeli'nin kendisiyle yüzleşmesini sağlayan bir "aşk nesnesi(dir).” (Badiou-Truong, 2017: 71). Bu nesneye baktığı an, Küçük Ağa’yı gerçekten sevdiğini itiraf etme sahnesidir.

Bu sır Zeli’nin Küçük Ağa'ya olan aşkının da kanıtıdır. Zeli’nin, Küçük Ağa ile ilk karşılaştığı andan itibaren bu aşkı bastırmaya çalıştığı görülür. Duyguları bastırmanın yansımalarından biri suskunluktur. Çünkü Zeli, Küçük Ağa'nın kendisini sürekli rahatsız ettiğini kocasına söylediği andan itibaren giderek susmuş ve içine kapanmaya başlamıştır. Bunun nedeni hem olacak kötülüklerden endişe duyması hem de Küçük Ağa'ya olan gizli sevdasıdır. Küçük Ağa'nın o gece eve gelince Zeli'nin suskun kalmasının nedeni yine bu gizli sevdadır. Çünkü Zeli, titreyen sesinin kendisini ele vereceğinden korktuğundan o gece sesini çıkarmamıştır. Ayrıca yörede kadınların bir âdetini yerine getirmemesi de bu sevdanın diğer işaretidir. Söz konusu yöredeki âdet göre; kadın, peşine düşen bir erkekten hoşlanmazsa onunla karşılaştığında kendi yüzüne ya çamur sürer ya ocağın isini. Zeli ise böyle bir şey yapmaz. Yine Küçük Ağa kaldıkları yere geldiğinde; Zeli'nin gece lambayı birden söndürmesi onu sevdiğinin bir başka göstergesidir. Çünkü o, sevdasının kendisini ele vereceğinden korktuğu için lambayı isteyerek söndürmüştür. "Geceleyin başka bir insanızdır, tamamen kendimizizdir." (Cioran, 2007: 107). Zeli, gündüz itiraf edemediğini bir bakıma gece lambayı söndürerek asıl niyetini ortaya koymuştur. Küçük Ağa öldürüldükten sonra Zeli'deki suskunluk da bu sevdanın bir işaretidir. Keto, günlerce yalvarsa da onu konuşturmayı başaramaz. Anlatıcı, Zeli'nin iç dünyasında olanları; "dışı sessiz içi avaz" (s.30) ifadesiyle dile getirir. Zeli’nin asıl susmaya başladığı zaman dilimi, Küçük Ağa'nın Beyaz Öküz'ün altına gömülmesiyle başlar:

O geceden beri yönünü Beyaz Öküz'e dönmez oldu. Zeli geceden beri elini ona süremez oldu. Beyaz Öküz'ün sabah akşam bakımını Keto yapmaya başladı. Beyaz Öküz'den korkuyordu Zeli. Ödü patlıyordu. Beyaz Öküz'ün bakışları ona ürkünç, bir tuhaf geliyor. Kuşkulu, canlı, parlak bakışlarıyla acı eken, yalvaran, soru dolu bir insanın bakışlarından farksızdı. Yönünü ne zaman dönse Beyaz Öküz orada. Bir Beyaz Öküz mü? Evinde ne varsa canlanmış, kıpır kıpır bakıyor, Zeli'ye bir şeyler diyorlardı. Zeli'nin içi şimdi o söylenen bu seslerle doluydu şimdi. (s.127).

Zeli, kendisinden üç adım ötedeki Beyaz Öküz'le göz göze geldikçe ciğeri yanar. Onun toprağı koklaması ve toprağı tırnağıyla kazımasını gördükçe içi parçalanır. Sabah akşam Küçük Ağa'nın mezarıyla yan yana olmak, Zeli'ye dünyadan el etek çektirir. Artık kocasının ayaklarını yıkamaz, suya gitmez, yemek pişirmez ve bir iş yapmaz olur. Ayrıca kimse şüphelenmesin diye de evden çıkmaz. Lambayı bile yakmadan karanlıkta oturur. Ruhu karanlığa büründüğü gibi 
bedeniyle de sanki karanlığa sığınmıştır. Zeli, Keto için bir yabancıdan farksız biridir. Keto'yu da yanına yaklaştırmamaktadır. Zeli, olanları kocasına söylemenin pişmanlığı, Küçük Ağa'nın ölümünün verdiği ıstırabın içinde kendi kendisiyle âdeta boğuşmaktadır. Bu nedenle Küçük Ağa'nın ölmesinde kendisini suçlar, öküze baktıkça insanlığından utanır, bir kementin boynunu sıktığını hisseder. Zeli'ye göre "ah ne çare ki dönen değirmenler bir daha dönmez geri. Öğünen un tane olmaz" artık. Zeli, oturdukları yer damında üç adım ötedeki Küçük Ağa'nın mezarının üstünde yatan Beyaz Öküz'e odaklanmaktan başka bir şey yapamamakta ve Küçük Ağa'dan başkasını düşünememektedir.

Ah içim bakıra kesmiş, gün kararır. Acılar işler içime acılar... Ne zaman baksam Beyaz Öküz karşımda. Yer damında soluyan, bakan yalnız o. O bakışları perran perran yüreğime saplanır. Öküz öküzken bile bakışları içime laf atar. Her bakışı içime konan bir baykuş... (s.134).

Beyaz Öküz'ün bakışlarında hep Küçük Ağa'yı gördüğünden vicdanı rahatsız olmaktadır. Beyaz Öküz'e baktıkça Küçük Ağa'yı hatırlar. Beyaz Öküz'ün bakışları acı çeken, yalvaran, soru dolu bir insanın bakışlarından farksızdır. Bütün varlıklar canlanmış, sanki kendisine bir şeyler söylemektedir. Burası artık kendisinin de mezarıdır. Hem kocasının yaptığı planın bir parçası olmanın hem de lambayı söndürmenin pişmanlığındadır. Zeli, kendi kendisiyle yüzleşince "hem olanın hem de olmayan”ın pişmanlığıyla yüz yüzedir. Yani olayı kocasına anlatmanın pişmanlığıyla vicdanı sızlamaktadır:

İçim tuhafları yaşar. Başım boşlukta sallanır. Dermanlar kâr etmez. Dışım sessiz. İçim avaz... Keşke dilim lal olaydı. Keşke o gece gelmeyeydin. Geldiğinde bağıraydım. Soluğum yetmeye, ciğerim kuruyaydı. Lambayı söndürmeyeydim. Ah, ahüzarlar almıș içimi, ahüzarlar... Gölgeler sabah akşam içimde gölgelenir. (...) Ruhumu sürmüşem ruhuna, ruhumu... (s. 130).

Küçük Ağa'dan geriye kalan hatıralar ise Zeli'nin ıstırabını ikiye katlar:

Bir gün bohçasının içinde Küçük Ağa 'nın ufacık aynasını buldu. Aynayı alıp avucuna baktı da kendisini gördü Zeli. Kıvırcık kara saçlı Küçük Ağa'yı gördü. Dayanamadı, aynayı kasığının üstüne bastırarak kapandı yüzükoyun Zeli. (s. 135).

Aynayı bulduğu an hikâyedeki en gerilimli anlardan biridir. Çünkü bu ayna Küçük Ağa'nın da Zeli’yi sevdiğini gösteren en önemli nesnedir. Ayna özel bir eşya olarak insandaki dört bellekten biri olan "nesneler belleği(ne)" (Assman, 2015: 27) karşılık gelir. Ayna, burada Zeli için bir unutma değil, hatırlama nesnesidir. Bir hatırayı içerisinde taşıyan ayna imgesi Zeli'nin geçmişin gözünde canlanmasını sağlar. Aynada Küçük Ağa'yı görür, sanki. Aynayı kasığına bastırarak yüzüstü yere kapanması onu unutamadığını gösterir. Hasan Ali Toptaş bu hikâyeyi okuyunca; "insan denilen yaratığın kendi gövdesinin sınırlarında bitmediğini, hayvanlara, bitkilere, dağlara ve denizlere doğru genişleyip gittiğini düşündüm. Sonra gördüğümüz her şeyi içimizde taşıdığımızı, gördüğümüz her şeyin ağırlığını ağırlığımıza eklediğimizi düşündüm." (Toptaş, 2018: 110) der. Yukarıdaki satırlar Doğu toplumlarında kadının gerçeğine ışık tutar. Çünkü kadın, kendi duygularını bastırmak zorundadır. Zeli'nin bu durumu, kadının iradesinin 
olmadığının da göstergesidir. "Gündelik hayatın ağırlığı kadınların üzerindedir. Kadınlar gündelik hayat içinde hem öznedirler, hem de gündelik hayatın kurbanlarıdırlar, dolayısıyla nesnedirler, ikamedirler (güzellik, dişilik, moda vs.). (...) Üstelik ikamelerin çoğalması kadınların aleyhinedir." (Lefebvre, 2013: 87).

Zeli iç dünyasında kendi kendisiyle çatışması devam ederken Keto'nun karısının garip ve anlaşılmaz halinden duyduğu kuşku her geçen gün daha çok artar. Keto, âdeta yalnız ve dipsiz bir karanlıkta yaşayan ve sessizliğe gömülen Zeli'nin bu sessizliğinin anlamını çözmek, anlamak ister. "Kişinin bașka kişileri, olayları, durumları, kendisini ve genellikle tek tek şeyleri değerlendirmesi insanın bir yapı özelliği, bir var olma şartıdır." (Kuçuradi, 2013: 7). Keto da karşı karşıya bulunduğu zorluğu düşünerek karısı yüzünden işlediği bir suçun nedenini sorgular. Çünkü o, Zeli’nin aklının Küçük Ağa'da kaldığını aklına getirmez değildir:

Dıştan emin görünse de içi alt üst olmuştu, tedirgindi çok. Ama içinin alacası dışına vurmuş değildi henüz. Onun korkusu Zeli'deydi. Zeli'nin Beyaz Öküz'den korktuğunu, ona elini bile sürmediğini biliyordu. Zeli'nin hali hal değildi. (s.133).

Bir süre sonra karısına öfke duymaya başlayan Keto, açıkça Zeli'ye bir suçlama getirememekle birlikte onun duygularının farkındadır. Çünkü ona göre "bu dünyada üç şeye güven olmazdı: "bunlardan biri ateş, biri su, biri de kadındı." (s. 134). Zeli, o geceden sonra değişir ve bambaşka biri olur. Davranışları, bakışları tuhaflaşır. Hep dalgın ve düşüncelidir. Oturduğu yerin artık bir mezar olduğunu düşündüğünden bu mezarla sabah akşam yan yana olmak Zeli'nin yüreğini dağlamaktadır. Çünkü "herkesin öğrenmek istediği bir gizi, bir insanın içinde tutması, bilip de söyleyememesi, taşıması ne zor bir yüktü." (s. 133). Keto, bir gece rüya mı gerçek mi olduğu belli olmayan bir ninni sesiyle uyanır. Sesin Beyaz Öküz'ün olduğu yer damından geldiğini fark eden Keto, bir de bakar ki bir aydan fazla zamandır Beyaz Öküz'e elini sürmeyen Zeli, şimdi Beyaz Öküz'ün boynuna sarılmış ağlayarak ağıta benzeyen hazin bir ninni söylemektedir:

Ruhumu sürmüşem sana. Seni içime manzara yapmışam. İçimin seyri sana dönmüş. Yüreğimin ötüşü senden yana. Ah gök altında olaydık. Elele verip dağ bayır gezeydik. Başımıza ak bulutlar konaydı. Kuşlar kanat çırpa çırpa uçaydı. Ruhumu sürmüşem sana. Ruhumu. (s.143).

Zeli, Beyaz Öküz'e baktıkça onun suratında Küçük Ağa'yı görmekte ve deliye dönmektedir. Istırabını daha fazla gizleyemeyerek iç dünyasını ağlayarak dışa vurur. Söylediği bu ninni, Küçük Ağa'nın sevdasına yaktığı ağıttır. Bu ağıt, Zeli'nin Küçük Ağa'ya olan aşkının da itirafıdır. Zeli'nin yaktığı ağıta tanık olan Keto'nun şüphesi iyice belirginleşir ve kadınlara güvenilmeyeceği düşüncesinde kendince haklı çıkar. Gözlerine inanamayan Keto'nun yapacağı tek şey Beyaz Öküz'ü öldürmek için keskin, tırtıklı bağ bıçağıyla ona saldırmaktır.

Yazarın yörenin ağız özelliklerini yansıttığı "seni içime manzara yapmışam" cümlesindeki “manzara” sözcüğü, Zeli’nin içindeki aşkın Beyaz Öküz'e baktıkça Küçük Ağa'yı görmeye devam edeceğinin bir işaretidir. "Sözcük seçimi öncelikle duyguların seçimidir.” (Borgna, 2019: 202). Osman Şahin’in kendi deyimiyle “öykü 
sözcüklerle yazılır. Sözcükler (ise) birer sestir, birer güçtür. (...) Her sözcük bir düşünce taşır içinde." (Güzel, 2013: 187). Ayrıca kelime bazen nesneleri de temsil edebilir ki, metinde "manzara” sözcüğü "ayna” nesnesine karşılık gelir. Ömer Lekesiz de "öykü sözcüklerle anlam kazanabilir ancak." (2006: 237) diyerek hikâyedeki "manzara" sözcüğünün seçiminin aşk duygusunu daha güçlü hissettirdiğini ifade eder.

Zeli’nin Beyaz Öküz'den gözünü ayıramaması ve sürekli sarılıp sevmesi hikâyenin en etkili yerlerinden biridir. Bu olay, Zeli ile Küçük Ağa'nın kavuşma sahnesidir. Keto, Zeli'nin yaptıklarına tanık olunca Küçük Ağa'yı öldürdüğü bıçağı alarak Beyaz Öküz'e saldırır. Onun Beyaz Öküz'ü öldürüp öldürmediği merak konusudur. Keto, Beyaz Öküz'ü de öldürerek Zeli'nin duygularını bitireceğini düşünür. Ama ölen Küçük Ağa'nın bedenidir, ruhu Zeli’yle yaşamaktadır.

\section{Namus}

Beyaz Öküz'de temel çatışmanın üzerine kurulduğu değerlerden biri de "namus" kavramıdır. Bu kavram hikâyede sınıfsal olarak yoksul insanlar tarafından verilen bir sınavdır. Metinde Anadolu insanının, yoksulluğu "kader" diyerek kabul edebileceği ancak namus belasına asla göz yummayacağı Cercis Ağa'nın ırgatlarından Keto aracılığıyla verilir. Hikâyede aşk unsuru bireysel planda açıklanabilecekken, namus toplumsal nedenlerle açılanabilir. Küçük Ağa'nın, Zeli'yi ilk gördüğü andan itibaren onun etrafında dönmesiyle birlikte, Zeli, namus konusunda hep toplumun değerlerini hatırlar. Ancak Küçük Ağa'nın verdiği hediyelerle birlikte Zeli'nin ruhunda bir çatlak oluşmuş ve namusu ile aşkı arasında kalmıştır. Zeli olanları Keto'ya söyledikten sonra evden hiç çıkmaz. Çünkü tedirgindir. Olanı biteni kocasına söylemekle iyi mi etmiştir kötü mü, onu bilememektedir. Onun aşk ile namus arasındaki ikilemi olaydaki gerilimi canlı tutar. Hikâye boyunca Keto'nun hırsı, öfkesi ve kıskançlığı, Zeli'nin ise vicdan azabı gerilimi besleyen diğer unsurlardır.

Keto, namusunu her şeyden üstün tutar. Keto, Zeli ile Küçük Ağa arasında herhangi bir şey olduğu duyulacak olursa bu namus yükünün altından kalkamayacağını düşünür. Küçük Ağa'nın Zeli’nin peşinde olduğu haberini duyduğu andan itibaren huzuru kaçar ve bu sorunu nasıl halledeceğini düşünüp durur:

Keto, parayı alınca uzun uzun düşündü. Şu dünyada Zeli’den başka nesi vardı ki? Tarlası mı, öküzleri mi, mülkü mü, parası mı? Hiçbiri... Bir Zeli’si vardı. Ölümü göze alıp Hurig'ten kaçırıp getirmişti onu da. Şimdi o helaline de Küçük Ağa göz dikmişti. Küçük Ağa ile açıktan bir tartışmaya giremezdi. Küçük Ağa dengine almazdı onu. Bir-iki laf ettikten sonra "hastir"i yapıştırır, kovardı köyünden. O zaman yeni evli başlarıyla nereye gidebilir, kime sığınabilirlerdi? (s. 116).

Onun bu olayı çözmesi, kendi sosyal ve kültürel seviyesine uygun şekilde gerçekleşecektir. Ölümü göze alıp kaçırdığı kadının, namusunu korumak için de 
gerekirse yeniden bu tehlikeyi yeniden göze alacaktır. Yazar onunla oldukça gerçekçi bir karakter örneği çizer. Keto'nun maddî imkânsızlığı onun bu problemi başka bir yolla çözmesine uygun görünmemektedir. Yoksulluk, onu bu belaya iten sebeplerin başında gelmektedir. Yoksul olması ve önünde kış olduğu için gidebilecek bir yerlerinin olmaması Keto'yu bu olayda acele davranmaya sevk edecektir. Yoksul olmaları Küçük Ağa'nın cesaretini beslediği gibi onların kaçıp başka bir yere gitmelerinin önünde de engeldir. Keto, acele davranarak kendisini kendi hapishanesine kapatır. Bir gerçek vardır ki Keto, bu olayı karııından duyduğundan itibaren artık "deli gömleği giydirilmiş" bir insana dönüşür. Karısının da kendisinin de artık bu ortamda rahat yaşaması imkânsız gibidir. Onun namusu için verdiği mücadele ve öfkesine yenilerek ölümle sonuçlanan bu olay aslında arka planda ezilmişlerin, ırgatların her hakkı kendisinde gören "ağalık"a karşı verilen tek kişilik bir mücadeledir. Yazar, Keto'nun tavrıyla; yoksulların onuru için verdiği mücadeleyi, Küçük Ağa'nınki ile de zengin sınıfın yoksulları hafife almasını eleştirir. Emil M. Cioran, hükmetmenin hem bir zevk hem de zaaf olduğunu söyler. (2007: 22). Bu düşünce Küçük Ağa'nın davranışına uyar. Çünkü o, bir güçlü olarak Zeli'yi hemen elde edebileceğini düşünmüştür. Ayrıca güçlünün güçsüzün onurunu ayaklar altına alması toplumsal problemlerden biridir. Yazar bu mesajı Keto üzerinden somutlaştıırı. Keto'nun anlayamadığı şey, bir ağanın kapısındaki bir ırgatın karısının namusuna göz koymasıdır. Keto, karşı karşıya bulunduğu problemle baş etmek için çıkış yolları ararken, toplumun asli değerlerini hatırlar. Evli bir kadının namusuna göz diken Küçük Ağa'nın amacını tam kavrayamayan Keto, namus kavramını hafife almasını kendine göre şöyle sorgular:

Ula bu nasıl yanlış hevestir? Bu nasıl edep haya düşkünü bir heriftir ki kendi marabasının öz namusuna rağbet ediy?...

Eli ayağı uyuştu Keto'nun. Canı çekildi sanki. Çöküp kaldı duvarın dibine. Karısının öyle usulca ağladığını görünce yanına vardı.

'Sen heç dert etme Zeli!' dedi. 'Üzme kendini! Bunda senin bir kabahatin ne ola? Demek ki Küçük Ağa yoluna yol olmuş seni düşünür. (s.118).

Keto ve Zeli, yoksullukla mücadele ederken bir de başlarına şimdi namus belası çıkmıştır. Hikâyedeki asıl gerilimi sağlayan da bu ikinci mücadele olacaktır. Keto bunları düşünürken Zeli korku ve tedirginlik içindedir. Zeli "olanı biteni kocasına söylemekle iyi mi, kötü mü etmişti?” Keto, namusuna bir leke sürdürmemek için çözüm ararken Zeli, kocasını böyle bir beladan haberdar etmenin pişmanlığını yaşamaktadır. Yazar, metinde Keto'nun ağzından Küçük Ağa'yı namus konusunda yargılamakla birlikte onun kişiliğine dair hiçbir ayrıntıdan bahsetmez. Ayrıca Zeli'nin de Keto'nun da geçmişiyle ilgili hiçbir bilgi vermez. Anlatıcının aktardığına göre Zeli henüz üç aylık bir gelindir. Keto'yla ilgili verilen bilgiler ise Zeli'yi karşı köylerden birinden ölümü göze alıp kaçırdığıdır. Keto'nun fiziksel özelliklerinde güçlülük vurgusu sezilmektedir:

Kısa boylu kara gözlü Keto. Canına çevikti. Uzun, gelişmiş kolları vardı. Ve o kollarının ucundaki elleri kemikli, yumru yumru büyüktü. (s. 114). 
Keto, yoksul ama namusunu her şeyin önünde gören, bundan zerre kadar taviz vermeyen, ancak problemleri akıl yoluyla çözemeyen insanı temsil eder. Toplumsal değerlere karşı duyarlılığı, davranışları, problemleri çözümleme biçimi onun kişiliğinin ipuçlarını verir. "Kişi ön plana koyduğu değerlere göre, sahip olduğu insan anlayışına göre; olayları ve durumları anlayışına, yorumlayışına göre; yaşamdan, insanlardan ve kendisinden beklediği şeylere göre eylemlerde bulunur." (Kuçuradi, 2013: 52). Keto'nun kişiliğine karşılık Küçük Ağa ise kendi sınıfsal üstünlüğünün verdiği gücü toplumun uygun görmediği yollardan kullanır. Küçük Ağa ile edinilen ilk izlenim ise; gücün her şeyi halledebileceğini düşünen biri olmasıdır. Ancak kendi sınıfından olmayan ve hizmetlerini gören evli bir kadının namusuna göz dikmesi onun kişiliğinin basitliğinin göstergesidir. Bu, Keto'nun anlam veremediği tek şeydir. Keto'nun bu konudaki yargıları toplumun sesidir. Küçük Ağa'nın Zeli'ye olan ilgisini; aşk duygusuyla açıklamak çok kolay olmamakla beraber, hükmü altındaki bir insanın namusuna göz dikmesi ve bunun toplumsal ahlâk değerlerine aykırı olması, onun hikâyede karşıt gücü temsil eden kişiler arasına koyulmasını gerektirir. Ayrıca Zeli'nin ona söylediği sözler namus kavramını önemsediğini göstermektedir:

Biz fakiriz Ağa'm! Bizim yükümüzün kahrı zengin. İkide bir karşıma çıkıp çıkıp da namus eziyeti çektirme bana! Yüreğimi ateşe sürme! Zayıf zebun etme beni!.

Bir yararı olmadı.

Bir keresinde bir ıssızda yoluna çıktı Küçük Ağa. Bakışlarıyla kuşatıp sardı Zeli’yi. Zeli ne yapacağını ne diyeceğini şaşırdı. Eli ayağı tutuldu. Küçük Ağa yanına yaklaşınca utandı, yüzünü eğdi. Sırtını döndü. Olduğu yere çömeldi. Aldırmadı Küçük Ağa. Yürüdü Zeli'nin arkasında durdu. (s. 115).

Hikâyedeki çatışmaların zenginliği bu metnin en güçlü yönlerinden biridir. Bu çatışmalar; Zeli'nin Keto'yla, Zeli’nin Küçük Ağa'yla, Keto'nun Küçük Ağa ile ve Zeli'nin kendi kendisiyle çatışmasıdır. Hikâyedeki çatışmaların en güçlüsü Zeli'nin kendi kendisiyle çatışmasıdır. Zeli etrafında yaşanılan çatışmalar, metindeki gerilim ve merak unsurunu da besler. Zeli'nin Küçük Ağa'nın tavrına nasıl karşılık vereceği, bunu Keto'ya söyleyip söylemeyeceği okurun merakını besleyen düğümler olduğu gibi, Küçük Ağa'nın kendi peșine düşmesini kocasına söylemesi, ardından bunun verdiği pişmanlık ve daha sonra Küçük Ağa'nın ölümünün verdiği ıstırap onun iç çatışmasının sebepleridir. Hikâyedeki ölüm unsuru kadar Zeli'nin iç dünyasındaki çatışmadan kaynaklanan ıstırabı da trajiktir. Keto ile Zeli'nin en uyumlu oldukları varlık ise doğadır. Zeli'nin Murat nehrinden su getirmesi, öküzlerle aynı mekânda yan yana yatmaları onların insana karşılık doğayla uyumlu olduklarını gösterir.

Zeli, duyguları ile toplumun değerleri arasında kalmıştır. Gönlü Küçük Ağa'dan yanayken aklı kocasından yanadır. Keto'nun onun kadınlık duygularını anlamaması ve onu "mal” olarak görmesi ikileminin başladığı ve çıkmaza girdiği yerdir. Küçük Ağa'nın onu etkilediği yönü “ağalık”ı değil, kendi kadınlığına verdiği değerdir. Zeli bu ikilemin verdiği duyguyla; “Küçük Ağa'ya kaçsa mıydı, yoksa bunu hiç Keto'ya söylemeseydi mi?” sorularını kendi kendisine sormadan edemez. Bu 
ikilem arasında gidip gelen Zeli, bir çıkış yolu bulamamış ve toplumun değerlerine karşı gelememiştir. Zeli, Küçük Ağa'ya varmasının toplumsal açıdan yanlış olduğunu bilse de gerçek manada onu sevmektedir. Metindeki aşk ve namus ikilemi, aslında akıl ve duygu arasında kalan insan gerçeğini gösterir. Çünkü Zeli'nin aklı Keto'ya ihanet etmemekten yanayken, duyguları Küçük Ağa'ya varmaktan yanadır. Yazar metinde bu ikilemi okura bırakır. Bir tarafta Küçük Ağa'ya duyduğu sevgi, diğer tarafta evli bir kadın olduğundan "toplum ne der?" düşüncesi vardır. Kararsızlık ve pişmanlığın bir bütün halini aldığı durum söz konusudur. Aslında yazarın asıl amacı, bireylerden çok toplumun böyle bir problemle yüzyıllardır yüz yüze olduğu mesajını vermektir. Çünkü Keto gibi birinin bu durumu kabullenmesi mümkün değildir. $O$, başına gelen olayda nasıl hareket edeceğini bilen ve davranışının neler doğurabileceğini hesaplayacak biri de değildir. Yazarın vermek istediği mesajlardan biri de bölgede kadının adının olmadığı, duygularının yok sayıldığıdır. Kocasının Zeli'ye bakışı, yazarın olayı kurguladığı toplumsal çevrede kadına verilen değeri gösterir. Doğu'da kadının birey olarak kendi kararını verememesi gibi bir problemle karşı karşıya kalması sonucunda Zeli, başa çıkamadığı sorunu çözmek için kocasına başvurmuştur; bu durum ise birçok olumsuzluğa yol açmıştır.

Keto'nun karısına olan bağlılığı sevgiden ziyade toplumsal değerlerle ilişkilidir. Bu bağlılık, "Zeli dünyasıydı onun, malıydı, her şeyiydi” (s.124) cümlesiyle yansıtılır. Onun Zeli’yi sevip sevmediği belli değildir. Keto'nun onun düşüncelerine ve duygularına değer ve karşılık vermediği açıktır. Karısına hediyeler içerisinden parayı almasını söyleyerek de bunu göstermiştir. Ayrıca ona göre kadın güvenilmemesi gereken bir varlıktır. Ona verdiği değeri başka birini öldürerek âdeta ispatlamaya çalışır. Bir maraba olarak acizlik gösterse de karısının namusu söz konusu olduğunda hiçbir şeyden çekinmez. Keto, Küçük Ağa'yı öldürdükten sonra Zeli'nin kaygılı hali karşısında ona söylediği cümleler toplumsal değerleri ne kadar önemsediğini gösterir:

Bir namus kirini öldürdüm diye korkun niyedir? Marabayız, yoksuluz diye bizim namusumuz elma değil ki elden ele verile. (s. 125).

Bu sözler, yazarın olayı kurguladığı toplumsal çevrede namus kavramına ve kadına verilen değeri de gösterir. Yazar hikâyede toplumcu gerçekçi bakışını ortaya koymak için “yoksulluk” u arka planda Doğu'daki önemli olumsuzluklardan biri olarak işler. Birçok hikâyesinde yoksulluğu tema olarak seçmesi nedeniyle onu yoksulların yazarı olarak görmek mümkündür. (Güzel, 2013: 107). Hikâyede aşk ve namus ikileminin kaynağında yoksulluk vardır. Zira Keto'yu namus belasına götüren sebep yoksulluktur. Bunun somut göstergesi kaldıkları yer damıdır. Burada sanki bir sığıntı durumundadırlar. Hikâyede esas mekân beyaz ve siyah öküzle birlikte kaldıkları yer damıdır. Mekânın aşağıdaki tasviri onların yoksulluğunu gözler önüne serdiği gibi Cercis Ağa'nın onlara verdiği değeri göstermesi bakımından önemlidir: 
Lambanın isi, kartal teleği gibi duvarı yukarı doğru karartmıştı. Duvarların yüzü yer yer çatlamış sıvalarla kaplıydı. Gübre, saman ve ot kokuyordu içerisi. Koyun ağılından bozma upuzun tek göz yer damının bir ucunda Cercis Ağa'nın iki öküzü bağlıydı; biri beyaz, biri siyah öküzler... (s.122).

Yazar, hikâyenin gerilimini üst seviyeye çıkararak namus kavramının önemini tam da burada ortaya koyar. Keto namusunu korumak, karısına sahip çıkmak için Küçük Ağa'yı istemeden de olsa öldürür. Pişmandır, çünkü onu öldürmeyi planlamamış ve işin sonunun böyle olmasını istememiştir. Zeli'nin, Küçük Ağa öldükten sonra içine kapanması ve suskunluğa bürünmesi ise onu çileden çıkarır:

Çok değil, bir ay öncesine kadar kocasının dilinin dönüşüne göre konuşan Zeli de şimdi ufak bir ses yoktu. (132).

Küçük Ağa'nın ölümünden sonra bütün huzuru kaçmasına rağmen içi rahatlamıştır. Keto, Küçük Ağa'yı öldürdükten sonra Zeli'nin korktuğunu görünce; "bir namus kirini öldürdüm diye korkun niyedir? Marabayız, yoksuluz diye bizim namusumuz elma değil ki elden ele verile." diyerek namusun toplumda her şeyin üstünde olduğunu vurgulamak ister. Keto'nun mücadelesi ağa baskısı altındaki insanların, onur meselesi söz konusu olunca her şeyi göze aldıkları gerçeğini de yansıtır. Osman Şahin, görev yaptığı Doğu ve Güneydoğu bölgelerine ilişkin gözlemlerini aktarırken; "Fırat insanının içgüdüleriyle yaşamlarını kaplayan rezilliğe karşı çıkarken, dış görünüşleriyle aynı düzene saygılılarmış gibi sürekli bir ikilemi yaşarlar. Çelişkilerle yüklü karşıtlıkların insanlarıdırlar." (Güzel, 2013: 107) der.

Hikâyede "toprak" bir simgedir. Toprak insanın ebedî sükûnunu da temsil eder. "Insan ebedi sükûnuna onun kolları arasında kavuşacak(tır)." (Turinay, 1996: 97). Küçük Ağa'nın yaptığı davranışı temizleyen ve onu örten toprak, Keto'nun cahilliğini temizlemenin de sembolüdür. Yine "gece" suçun ve gizliliğin simgesi olarak yer alır. Keto, Zeli'ye "gece dediğinin ömrü kısadır ve de çabuk geçer." derken sanki o gece olacakları sezdirmiştir. Beyaz ve siyah öküz ise aşk ve namus ikilemini temsil etmiştir. Aşk ölmüş namus ise ruh kirlense de bedenen temiz kalmıştır.

Beyaz Öküz hikâyesini "kora şeması"na (Korkmaz, 2007: 147) göre aşağıdaki şekilde şematize etmek mümkündür:

\begin{tabular}{|c|c|c|}
\hline & Tematik Değer & Karşıt Değer \\
\hline Kişiler & Zeli, marabalar, köylüler & Keto, Küçük Ağa \\
\hline
\end{tabular}




\begin{tabular}{|c|c|c|}
\hline Kavramlar & Aşk, namus, onur, vicdan & $\begin{array}{r}\text { Ölüm, yoksulluk, ağıt, ıstırap, korku, } \\
\text { güç, ağalık, kıskançlık, öfke, } \\
\text { pişmanlık, ikilem, yalan, töre }\end{array}$ \\
\hline Simgeler & $\begin{array}{c}\text { Beyaz Öküz, ayna, çiçek, } \\
\text { saç tokası, toprak, ninni, } \\
\text { ağıt, kurban }\end{array}$ & Bıçak, kan, para, gece, lamba \\
\hline
\end{tabular}

\section{Sonuç}

Edebî metinler her zaman insanla ilgili gerçek ve gerçeklikleri yansıtır. Osman Şahin, birçok hikâyesi gibi Doğu ve Güneydoğu Anadolu bölgesindeki gözlemlerinin yansıdığı bu hikâyesinde, yöreyle ilgili insan ve toplum gerçekliklerini metne taşır. Bazı sosyal eleştirileri de içeren bu metnin amacı yazarın ideolojisine hizmet etme amacı taşır. Beyaz Öküz hikâyesi, Anadolu insanının namusu ve onuru uğruna her tehlikeyi göze alabileceği gibi, aşkın da insanın mantığını körelterek gerçekleri görmesini engellediğini gösterir. Şahin, bu hikâyede kırsal kesimdeki yoksul insanların verdiği geçim mücadelesi kadar onur mücadelesini de gerçekçi bir şekilde yansıtır. Hikâyedeki kişilerin dünyasında gözlemlenen toplumsal değerler, bireysel davranışlar ve batıl inanışların hepsi Doğu ve Güneydoğu Anadolu bölgesinde görülebilecek cinsten olaylardır. Yazar hikâyesinde karakterleri ile çevreyi gerçekçi bir şekilde yansıtırken başarılıdır, ancak onları konuştururken ağız özellikleri konusunda tutarlı olduğu söylenemez. Çünkü söz konusu yörenin insanlarının konuşmaları ile hikâyedeki konuşmalar birbirinden farklıdır.

Şaşırtıcı bir sonla biten hikâyenin sonucunu toplumun değer yargıları belirler. Başkişinin pişman olmasına neden olan olayları kocasına söyleten, kocasını eyleme geçiren Küçük Ağa'yı ölümle cezalandıran düşüncenin gerisinde toplumun değerleri saklıdır. Biri “ağa” olmanın yani gücü elinde bulundurmanın verdiği cesaretle toplumsal ahlaka aykırı davranarak hayatını kaybeder, diğeri de olayda acele davranarak kendi onurunu kurtarmanın verdiği rahatlığı duyar. Ancak bu rahatlığın yanında diğer taraftan kendisini kendi hapishanesine kapatmış olur. Yazar, Doğu insanının, geleneklerine göre yaşarken bir taraftan da bu geleneklerle kendi kendisine duvar ördüğünü ve bir çıkmaza girdiğini vurgular. Ancak maddi olarak zayıf insanların her şeye karşın namusunu yaşama sebebi olarak bildiği ve onurunu her şeyden üstün tuttuğu da bir gerçektir. Söz konusu insanların yoksulluğu bir kader olarak görmelerine karşın, namus belası için aynı düşünceyi taşımadıkları anlaşılır. Yazarın olayda asıl eleştirmek istediği şey; bu yöredeki kadınların iradesinin elinden alındığının, her ne şartta olursa olsun 
duygularını bastırması gerekliliğinin yanlışlığıdır. Küçük Ağa'nın kayboluşundan sonraki dini inanışlara somut biçim kazandıran ritüeller ve batıl inanışlar yazarın arka planda yöreyle ilgili eleştirdiği diğer vurgulardır.

\section{Kaynakça}

Aktaş, Ş. (2004). Refik Halit Karay. Ankara: Akçağ Yayınları.

Assman, J. (2015). Kültürel Bellek. (Çev: Ayşe Tekin). İstanbul: Ayrıntı Yayınları.

Badiou, A. - Truong, N. (2017). Aşka Övgü. (Çev: Orçun Türkay). İstanbul: Can Yayınları. 2. Baskı.

Borgna, E. (2019). Ruhun Yalnızlığı. (Çev: Meryem Mine Çilingiroğlu). İstanbul: Yapı Kredi Yayınları.

Cioran, E. M. (2007). Ezeli Mağlup. (Çev: Haldun Bayrı). İstanbul: Metis Yayınları.

Gasset, J. O. Y. (2011). Sevgi Üstüne. (Çev: Yurdanur Salman). İstanbul: Yapı Kredi Yayınları.

Güzel, M. Ş. (2013). Öykücülüğümüzün Toros Zirvesi Osman Şahin. İstanbul: Kaynak Yayınları.

Korkmaz, R. (2007). "Romanda Mekânın Poetiği". Dil ve Edebiyat Yazıları/Mustafa İsen Armağanı. (Edt: A.Külahlıoğlu İslam-Süer Eker). Ankara: Grafiker Yayınları. s. 399-416.

Kuçuradi, ì. (2013). İnsan ve Değerleri. Ankara: Türkiye Felsefe Kurumu Yayınları.

Lefebvre, H. (2013). Modern Dünyada Gündelik Hayat. (Çev: Işın Gürbüz). İstanbul: Metis Yayınları.

Lekesiz, Ö. (2006). Kuramdan Yoruma Öykü Yazıları. İstanbul: Selis Yayınevi.

Şahin, O. (1990). Acı Duman. İstanbul: Milliyet Yayınları. 2. Baskı.

Toptaş, H. A. (2018). "Seni İçime Manzara Yapmışam”. Türkçenin Büyüme Tarihi. (Der: Murathan Mungan). İstanbul: Metis Yayınları. s. 107-110.

Şakar, C. (2014). Edebiyat Ne Söyler. İstanbul: İz Yayıncılık.

Tunç, G. (2020). Şiir ve Bellek. İstanbul: Ötüken Yayınları.

Turinay, N. (1996). Geleneğin Dünyası Yeniliğin Ufukları. Ankara: Akçağ Yayınları. Yılmaz, S. (2010). Osman Şahin'in Hikâyeleri (Yapı-Tema-Anlatım). Yayınlanmamış Yüksek Lisans Tezi. Gazi Üniversitesi, Ankara. 